\title{
SUPLEMENTASI RAGI ROTI (Saccharomyces cerevisiae) DALAM PAKAN PEMBESARAN IKAN BARONANG (Siganus guttatus)
}

\author{
Kamaruddin*\#, Lideman**), Usman*), dan Bunga Rante Tampangallo*) \\ *) Balai Riset Perikanan Budidaya Air Payau dan Penyuluhan Perikanan \\ J.. Makmur Dg. Sitakka No. 129, Maros 90511, Sulawesi Selatan \\ *) Balai Budidaya Air Payau Takalar
}

(Naskah diterima: 3 Desember 2018; Revisi final: 24 Juni 2019; Disetujui publikasi: 26 Juni 2019)

\begin{abstract}
ABSTRAK
Pemanfaatan Saccharomyces cerevisiae yang disuplementasikan dalam pakan buatan berbasis protein nabati mampu meningkatkan pertumbuhan beberapa jenis ikan budidaya. Penelitian ini bertujuan untuk mengevaluasi pengaruh suplementasi S. cerevisiae dalam pakan pembesaran ikan baronang. Hewan uji yang digunakan adalah ikan baronang dengan bobot awal antara 30-32 g/ekor. Perlakuan yang dicobakan adalah pakan dengan: tanpa suplementasi S. cerevisiae (S0; kontrol), suplementasi S. cerevisiae $2 \%$ (S2), suplementasi S. cerevisiae $4 \%(\mathrm{~S} 4)$, dan suplementasi S. cerevisiae $6 \%(\mathrm{S6})$. Wadah penelitian yang digunakan adalah waring hitam berukuran $1 \mathrm{~m} \times 1 \mathrm{~m} \times 2 \mathrm{~m}$, dengan kedalaman air 1,5 m; ditebari ikan uji dengan kepadatan 20 ekor/wadah. Metode yang digunakan dalam penelitian ini adalah metode eksperimen dengan menggunakan rancangan acak lengkap (RAL). Pemberian pakan dilakukan dua kali sehari sebanyak 4\%dari biomassa ikan uji. Hasil penelitian menunjukkan bahwa penambahan $2 \%$. cerevisiae dalam pakan memberikan respons pertambahan bobot dan laju pertumbuhan spesifik yang lebih tinggi $(P<0,05)$ dibandingkan dengan perlakuan lainnya. Nilai koefisien kecernaan total pakan relatif sama antara perlakuan S2, S4, dan $\mathrm{S6}$, namun ketiganya lebih tinggi dan berbeda nyata $(\mathrm{P}<0,05)$ dengan kontrol (SO). Jumlah sel darah merah (eritrosit) dan aktivitas fagositosis mengalami peningkatan secara signifikan $(P<0,05)$ seiring dengan penambahan S. cerevisiae dibanding kontrol (SO). Suplementasi S. cerevisiae dapat dilakukan sebanyak $2 \%$ dalam formulasi pakan ini untuk pembesaran ikan baronang.
\end{abstract}

KATA KUNCl: Saccharomyces serevisiae; pakan; pembesaran; baronang

ASBTRACT: Suplementation of brewers' yeast (Saccharomyces cerevisiae) in diets for rabbitfish grow-out. By: Kamaruddin, Lideman, Usman, and Bunga Rante Tampangallo

The utilization of Saccharomyces cerevisiae supplemented in artificial feed of protein plant-based can increase the growth of several of aquaculturefish species. This study was aimed to evaluate the effect of $\boldsymbol{S}$. cerevisiaesupplementation in artificial diet on the growth performance of rabbitfish. The test animals used were rabbitfish with an initial weight of 30-32 g/fish. The treatments tried were artificial diets with: no supplementation of $\mathbf{S}$. cerevisiae ( $\mathrm{S} 0$; control), supplementation of $\mathbf{S}$. cerevisiae $2 \%$ (S2), supplementation of $\mathbf{S}$. cerevisiae $4 \%$ (S4), and supplementation of $\mathbf{S}$. cerevisiae $6 \%(S 6)$. The fish were reared in twelve net cages of $1 \mathrm{~m} \times 1 \mathrm{~m} \times 2 \mathrm{~m}$, with a density of 20 ind./cage. Completely randomized design was used in this experiment. The fish were fed with test diets twice a day as much as $4 \%$ of total biomass. The results showed that the supplementation of $2 \%$ S. cerevisiae in diet gave higher weight gain and specific growth rate $(P<0.05)$ than those of other treatments. The value of total feed digestibility coefficient was relatively the same between treatments $\mathrm{S2}, \mathrm{S4}$, and $\mathrm{S6}$, but the three of them were higher and significantly different $(\mathrm{P}<0.05)$ than the control $(\mathrm{S} 0)$. The number of red blood cells (erythrocytes) and phagocytic activity increased significantly $(\boldsymbol{P}<0.05)$ along with the supplementation of $\mathbf{S}$. cerevisiae compared to control (SO). Supplementation of S. cerevisiae could be done as much as $2 \%$ in feed formulation for grow-out of rabbitfish.

\section{KEYWORDS: Saccharomyces serevisiae; feed; grow-out; rabbitfish}

\footnotetext{
\# Korespondensi: Balai Riset Perikanan Budidaya Air Payau dan Penyuluhan Perikanan. Jl. Makmur Dg. Sitakka No. 129, Maros 90511, Sulawesi Selatan, Indonesia

Tel.: + 62411371544

E-mail: dgbilla@yahoo.com
} 


\section{PENDAHULUAN}

Ikan baronang (Siganus guttatus Bloch) termasuk ikan laut yang mempunyai nilai ekonomi tinggi, karena selain dikonsumsi dalam negeri juga merupakan komoditi ekspor. Sampai saat ini produksi ikan baronang masih mengandalkan hasil tangkapan dari alam, sementara permintaan terus meningkat. Kegiatan penangkapan secara intensif tidak dapat dilakukan terus-menerus jika tidak diimbangi dengan kegiatan perbenihan, restocking, dan budidaya. Upaya perbenihan dan budidaya pembesaran merupakan keharusan untuk memenuhi permintaan yang terus meningkat dan mencegah penurunan populasi, serta kepunahan spesies tertentu seperti baronang, Siganus guttatus.

Usaha budidaya ikan secara intensif menuntut tersedianya pakan dalam jumlah yang cukup, berkualitas, tepat waktu, dan berkesinambungan. Secara umum, harga pakan ikan cenderung semakin mahal, sementara harga ikan hasil budidaya cenderung relatif stabil, sehingga tingkat keuntungan pembudidaya menjadi relatif rendah. Oleh karena itu, agar pendapatan pembudidaya tidak menurun, maka salah satu upaya yang dapat dilakukan adalah meningkatkan laju pertumbuhan ikan, sintasan ikan, dan tingkat efisiensi pemanfaatan pakan oleh ikan budidaya.

Saccharomy cescerevisiae merupakan salah satu jenis ragi (khamir) yang bermanfaat untuk pakan ternak, namun sejalan dengan waktu kemudian mulai dipakai untuk keperluan bioteknologi industri (Wotzon et al., 1988). S. cerevisiae juga mulai dipakai sebagai probiotik dan imunostimulan untuk meningkatkan kesehatan dan produktivitas ternak seperti ruminansia, unggas, dan ikan (Olivia-Teles \& Goncalves, 2001; Pais et al., 2008; Welker et al., 2007). Sebagai imunostimulan, karena dinding sel $C$. cerevisiae mengandung $\beta$ 1,3 dan 1,6 glukan (Life Source Basic, 2002).

Sebagai probiotik, cendawan ini dapat memiliki beberapa mekanisme antara lain meningkatkan responimun, berkontribusi enzim dalam pencernaan pakan, dan sebagai sumber makro dan mikro-nutrien (Verschuere et al., 2000). Selanjutnya Afrianto (2009) menambahkan bahwa dalam meningkatkan tingkat kecernaan pakan, probiotik antara lain akan menciptakan keseimbangan flora usus dan sebagai fermen dalam proses fermentasi. Berdasarkan informasi di atas, maka penelitian ini bertujuan untuk mengevaluasi pengaruh suplementasi $\mathrm{S}$. cerevisiae dalam pakan terhadap pertumbuhan, pemanfaatan pakan, dan respons imun juvenil ikan baronang.

\section{BAHAN DAN METODE}

Penelitian ini dilakukan di Instalasi Keramba Jaring Apung dan Perbenihan Udang Windu Balai Riset Perikanan Budidaya Air Payau dan Penyuluhan Perikanan (BRPBAP3) Maros yang berlokasi di Desa Lawallu Kabupaten Barru, Sulawesi Selatan.

\section{Pakan Uji}

Pakan uji berupa pelet yang memiliki kandungan isoprotein dan isoenergi. Pakan uji tersebut disuplementasi $\mathrm{S}$. cereviceae dengan dosis berbeda sebagai perlakuan yaitu: $0 \%(\mathrm{~S} 0), 2 \%(\mathrm{~S} 2), 4 \%(\mathrm{~S} 4)$, dan $6 \%(\mathrm{~S} 6)$, dengan formulasi seperti disajikan pada Tabel 1.

\section{Hewan Uji Baronang}

Hewan uji yang digunakan adalah juvenil ikan dengan bobot awal 30-32 g/ekor yang diperoleh dari hasil tangkapan di alam. Pada kegiatan pembesaran, hewan uji tersebut dipelihara dengan menggunakan wadah berupa 12 unit jaring keramba berukuran $1 \mathrm{~m}$ $\times 1 \mathrm{~m} \times 2 \mathrm{~m}$, ditebar dengan kepadatan awal sebanyak 20 ekor per $1,5 \mathrm{~m}^{3}$. Metode yang digunakan dalam penelitian ini adalah metode eksperimen dengan menggunakan rancangan acak lengkap (RAL) yang terdiri atas empat perlakuan dan tiga ulangan. Ikan diberi pakan uji sebanyak 4\%dari bobot biomassa yang diberikan dua kali sehari selama 120 hari pemeliharaan pada pukul 08.00 dan 16.00. Sampling pertumbuhan dilakukan setiap 30 hari untuk menyesuaikan jumlah pemberian pakannya.

\section{Uji Kecernaan Pakan}

Pengamatan kecernaan pakan dilakukan dengan menggunakan wadah percobaan berupa 12 tanki conical fibre glass bervolume $200 \mathrm{~L}$ dan diisi air bersalinitas 25-30 ppt, sebanyak $150 \mathrm{~L}$, sistem air mengalir dan dilengkapi dengan aerasi. Ikan baronang berukuran 30-32 g/ekor ditebar dengan kepadatan 20 ekor/tanki. Pakan uji tersebut ditambahkan kromium oksida $\left(\mathrm{Cr}_{2} \mathrm{O}_{3}\right)$ sebagai indikator sebanyak 0,70\% (Takeuchi, 1988). Ikan diberi pakan secara satiasi dua kali sehari pada pukul 08.00 dan 12.00. Sekitar 30 menit setelah pemberian pakan, air dikeluarkan untuk membuang sisa pakan dengan membuka kran. Adaptasi pakan uji selama satu minggu, lalu pengumpulan feses dilakukan setiap jam untuk mencegah terjadi leaching nutrien pada feses. Feses yang terkumpul secepatnya disimpan dalam freezer hingga cukup untuk analisis kemudian dikeringkan. 
Tabel 1. Formulasi dan komposisi proksimat pakan uji (\%bobot kering)

Table 1. Formulation and proximate composition of test diets (\%dry weight)

\begin{tabular}{lcccc}
\hline \multirow{2}{*}{$\begin{array}{c}\text { Bahan } \\
\text { Ingredients }\end{array}$} & \multicolumn{4}{c}{ Pakan uji (Test diets) } \\
\cline { 2 - 5 } & S-0 & S-2 & S-4 & S-6 \\
\hline Tepung ikan local/Local fish meal (\%) & 30 & 30 & 30 & 30 \\
Mie apkiran/Rejected noodle (\%) & 13.5 & 11.5 & 9.5 & 7.5 \\
Bungkil kopra/Copra cake meal (\%) & 15 & 15 & 15 & 15 \\
Ampas tahu/Tahu wasted (\%) & 10 & 10 & 10 & 10 \\
Dedak halus/Rice bran (\%) & 10 & 10 & 10 & 10 \\
Tepung gosse/Algae flour (\%) & 20 & 20 & 20 & 20 \\
Vitamin/Nitamin & 1 & 1 & 1 & 1 \\
Mineral/Mineral & 0.5 & 0.5 & 0.5 & 0.5 \\
Scerevisiae & 0 & 2 & 4 & 6 \\
\hline Komposisi proksimat (Proximate composition) & & & & \\
- Protein kasar/Crude protein (\%) & 29.3 & 29.1 & 28.9 & 28.7 \\
- Lemak/Crude lipid (\%) & 5.8 & 5.8 & 5.76 & 5.69 \\
- Serat kasar/Crude fibre(\%) & 9.12 & 9.08 & 9.05 & 9.02 \\
- Abu/Ash (\%) & 13.20 & 13.10 & 12.9 & 12.8 \\
- BETN/NFE (\%) & 42.58 & 42.92 & 43.39 & 43.79 \\
\hline
\end{tabular}

\section{Pengamatan Imunitas Ikan}

Pengamatan pengaruh perlakuan terhadap imunitas ikan uji dilakukan dengan cara mengambil sampel darah (Stolen, 1990). Sampel darah ikan masing-masing diambil dari tiga ekor ikan/perlakuan. Ikan yang diambil darahnya dibius terlebih dahulu dengan menggunakan minyak cengkeh dengan dosis $0,1 \mathrm{~mL} /$ liter air laut. Sampel darah ikan diambil pada bagian pangkal ekor ikan dengan menggunakan syringe ukuran 26 gauge yang sebelumnya telah dibilas dengan antikoagulan (3,8\% trisodiumcitrat). Darah ikan yang diperoleh kemudian ditampung ke dalam mikrotube volume 1,5 $\mathrm{mL}$ (Stolen, 1990).

Pengamatan jumlah sel darah merah (eritrosit) dilakukan dengan cara mengambil sampel darah sebanyak $5 \mu \mathrm{L}$ dengan menggunakan mikro pipet lalu dimasukkan ke dalam mikrotube yang baru yang berisi larutan Hayem $495 \mu \mathrm{L}$. Larutan darah ini kemudian diaduk agar homogen lalu diteteskan ke hemasitometer lalu diamati di bawah mikroskop cahaya dengan pembesaran $400 x$.

Aktivitas fagositosis diamati dengan cara mempersiapkan bakteri Stapilococcus sp. terlebih dahulu. Setelah bakteri siap, maka darah ikan baronang yang telah ditampung dalam mikrotube tadi disentrifuge selama lima menit pada kecepatan 1.000 rpm. Darah putih yang terbentuk di bagian paling atas diambil sebanyak 5-10 $\mu$ L lalu dimasukkan ke dalam mikroplate well. Stapilococcus sp. yang telah disiapkan sebelumnya, diambil sebanyak 5-10 $\mu$ L lalu dimasukkan ke dalam darah putih yang telah disiapkan sebelumnya dalam mikroplate well. Campuran darah ini kemudian diaduk dengan cara pipetting supaya darah putih dan Stapilococcus sp. tercampur sempurna. Diinkubasi selama 20-30 menit lalu diambil sebanyak $5 \mu \mathrm{L}$ dan diteteskan di atas glass object lalu dibuat preparat ulas. Preparat ini kemudian dikeringanginkan lalu difiksasi dalam ethanol 95\% selama lima menit, dikeringanginkan dan seterusnya diwarnai dengan menggunakan Giemsa 7\% selama 10-30 menit (Stolen, 1990). Preparat ini kemudian dibilas dengan menggunakan air mengalir lalu diamati di bawah mikroskop dengan pembesaran 400-1.000x.

\section{Perhitungan Respons Pertumbuhan, Pemanfaatan Pakan Uji, dan Sistem Imunitas}

Peubah pertumbuhan ikan baronang yang dihitung setelah aplikasi pakan uji selama 120 hari adalah:

(1) Laju pertumbuhan spesifik (SGR) ikan dihitung berdasarkan formulasi berikut (Schulz et al., 2005):

$$
\operatorname{SGR}\left(\% \text { day }^{-1}\right)=100 \times \frac{(\operatorname{Ln} W e-\operatorname{Ln} W s)}{d}
$$

di mana:

We $=$ bobot ikan pada akhir percobaan $(\mathrm{g})$

$\mathrm{Ws}=$ bobot ikan pada awal percobaan $(\mathrm{g})$

$\mathrm{d}=$ periode pemeliharaan (hari) 
(2) Efisiensi pakan (FE) (Takeuchi, 1988)

$\mathrm{FE}=\frac{\text { Pertambahan bobot ikan ( } \mathrm{g} \text { bobot basah) }}{\text { Jumlah konsumsi pakan ( } \mathrm{g} \text { bobot kering) }}$

(3) Sintasan

$$
\text { Sintasan }(\%)=\frac{\text { Jumlah ikan akhir }}{\text { Jumlah ikan awal }} \times 100
$$

(4) Koefisien kecernaan (AD) total pakan (bahan kering) $(\mathrm{DM})$, protein kasar (CP), dan lemak (L) dihitung berdasarkan rumus (Takeuchi, 1988; Hardy, 1989) berikut:

$$
\mathrm{AD}(\%)=100 *\left\{1-\left(\frac{\mathrm{M}_{\mathrm{D}} * \mathrm{~A}_{\mathrm{F}}}{\mathrm{M}_{\mathrm{F}} * \mathrm{~A}_{\mathrm{D}}}\right)\right\}
$$

di mana:

$\mathrm{M}_{\mathrm{D}}$ dan $\mathrm{M}_{\mathrm{F}}$ berturut-turut adalah konsentrasi indikator $\mathrm{Cr}_{2} \mathrm{O}_{3}$ (\%bobot kering) dalam pakan dan feses

$A_{D}$ dan $A_{F}$ adalah konsentrasi nutrient (\%bobot kering) dalam pakan dan feses

(5) Jumlah sel eritrosit dihitung secara manual lalu dimasukkan ke dalam rumus (Stolen, 1990) berikut:

$$
\mathrm{H}=\frac{\mathrm{T}}{5} \times 25 \times \mathrm{p} \times 10^{\wedge} 4 \mathrm{sel} / \mathrm{mL}
$$

di mana:

$\mathrm{H}=$ total sel eritrosit (sel/mL)

$T=$ total sel darah yang dihitung

$\mathrm{p}=$ pengenceran

(6) Aktivitas fagositosis (\%) dihitung dengan menggunakan rumus (Stolen, 1990) berikut:

$$
\operatorname{AF}(\%)=\frac{\left(\sum \text { fagosit yang aktif }\right)}{\left(\sum \text { fagosit yang diamati }\right)} \times 100 \%
$$

Analisis proksimat pakan dan feses dilakukan berdasarkan AOAC (1999): bahan kering (DM) dikeringkan dengan oven pada suhu $105^{\circ} \mathrm{C}$ selama 16 jam, serat kasar dengan ekstraksi ether, abu dengan pembakaran dalam muffle furnace pada suhu $550^{\circ} \mathrm{C}$ selama 24 jam dan protein kasar dianalisis dengan micro-Kjeldahl, lemak dideterminasi secara gravimetric dengan ekstraksi chloroform: methanol pada sampel. Kadar kromium dalam sampel pakan dan feses dianalisis berdasarkan prosedur Takeuchi (1988).

Peubah laju pertumbuhan ikan, efisiensi pakan, sintasan ikan, kecernaan total pakan, kecernaan protein pakan, kecernaan lemak pakan, total eritrosit, dan aktivitas pagositosis dianalisis ragam dan uji lanjut dengan uji beda nyata terkecil (BNT) (Steel $\&$ Torrie, 1995); sedangkan data kualitas air dianalisis secara deskriptif.

\section{HASIL DAN BAHASAN}

Respons biologi pemanfaatan $\mathrm{S}$. cerevisiae dalam pakan pembesaran ikan baronang di keramba jaring apung selama 120 hari disajikan pada Tabel 2 .

Berdasarkan Tabel 2 menunjukkan bahwa penambahan S. cerevisiaesebanyak S2 (2\%) dalam pakan pembesaran ikan baronang dapat memberikan respons pertambahan bobot dan laju pertumbuhan spesifik yang paling tinggi, berdasarkan uji statistik menunjukkan hasil yang berbeda $(P<0,05)$ dengan perlakuan lainnya. Hal ini juga didukung oleh nilai kecernaan total pakan pada perlakuan S2 cenderung lebih tinggi dibandingkan dengan perlakuan lainnya, meskipun berdasarkan uji statistik hanya berbeda nyata $(P<0,05)$ dengan perlakuan kontrol (SO). Hasil penelitian ini sama dengan yang dilaporkan oleh Afrianto (2009), bahwa penambahan $2 \%$ S. cerevisiae dalam pakan ikan nila merah (Oreochromis niloticus) menghasilkan pertambahan bobot dan laju pertumbuhan harian tertinggi sebesar $1,53 \%$ serta nilai rasio konversi pakan yang paling rendah yaitu 3,04 . Selanjutnya Abdel-Tawwab et al. (2008) melaporkan bahwa penambahan $1 \mathrm{~g}$ ragi roti $/ \mathrm{kg}$ pakan yang diberikan selama 12 minggu pada ikan nila (Oreochromis niloticus) dapat meningkatkan pertumbuhannya.

Peningkatan pertumbuhan ikan ini diduga disebabkan karena $S$. cerevisiae mengandung nukleotida. Pernyataan ini dilaporkan oleh Li \& Gatlin (2006) bahwa S. cerevisiae mengandung nukleotida dalam bentuk basah purin dan pirimidin sebanyak 0,9\% Begitu pula yang dilaporkan oleh Lin et al. (2009) bahwa penambahan nukleotida dalam pakan ikan kerapu yang diberikan selama delapan minggu dapat meningkatkan pertambahan bobot ikan yang lebih tinggi bila dibandingkan dengan ikan yang diberi pakan tanpa penambahan nukleotida. Burrels et al. (2001) melaporkan bahwa nukleotida dapat meningkatkan pertumbuhan karena nukleotida yang terkandung dalam S. cerevisiae dapat meningkatkan nafsu makan ikan sehingga pemanfaatan pakan meningkat. Sementara Barnes (2006) melaporkan bahwa nukleotida merupakan nutrien semi-esensial yang dibutuhkan untuk pertumbuhan dan perbanyakan sel. Sajeevan et al. (2006) menyatakan bahwa nukleotida yang ditambahkan dalam pakan dapat mengo ptimalkan fungsi pembelahan sel, termasuk sel-sel imun. Hal yang sama ditemukan oleh Abdel-Tawwab et al. (2008) bahwa penambahan $1 \mathrm{~g}$ ragi roti $/ \mathrm{kg}$ pakan yang diberikan selama 12 minggu pada ikan nila (Oreochromis niloticus) 
Tabel 2. Performansi pertumbuhan dan pemanfaatan pakan uji yang disuplementasi S. cerevisiae dengan dosis berbeda untuk pembesaran ikan beronang

Table 2. Growth performance and feed efficiency of rabbitfish fed with test diets supplemented with different doses of $\mathbf{S}$. cerevisiae

\begin{tabular}{lcccc}
\hline \multicolumn{1}{c}{ Peubah } & \multicolumn{4}{c}{ Pakan uji (Test diets) } \\
\cline { 2 - 5 } Variables & S-0 & S-2 & S-4 & S-6 \\
\hline $\begin{array}{l}\text { Rata-rata bobot awal } \\
\text { Average initial weight (g/ind.) }\end{array}$ & $31.17 \pm 1.12$ & $31.53 \pm 047$ & $31.87 \pm 0.72$ & $31.47 \pm 0.41$ \\
$\begin{array}{l}\text { Rata-rata bobot akhir } \\
\text { Average final body weight (g/ind.) } \\
\text { Rata-rata pertambahan bobot }\end{array}$ & $167.64 \pm 1.03^{\mathrm{b}}$ & $171.36 \pm 1.02^{\mathrm{a}}$ & $161.63 \pm 1.05^{\mathrm{c}}$ & $162.70 \pm 1.01^{\mathrm{c}}$ \\
$\begin{array}{l}\text { Average weight gain (g/ind.) } \\
\text { Laju pertumbuhan bobot spesifik (\%/hari) } \\
\text { Specific growth rate of body weight (\%/day) }\end{array}$ & $1.14 \pm 0.01^{\mathrm{b}}$ & $1.16 \pm 0.01^{\mathrm{a}}$ & $1.08 \pm 0.03^{\mathrm{c}}$ & $1.10 \pm 0.01^{\mathrm{c}}$ \\
$\begin{array}{l}\text { Sintasan } \\
\text { Survival rate (\%) }\end{array}$ & $100 \pm 0.00^{\mathrm{a}}$ & $100 \pm 0.0^{\mathrm{a}}$ & $100 \pm 0.00^{\mathrm{a}}$ & $99 \pm 0.57^{\mathrm{a}}$ \\
$\begin{array}{l}\text { Efisiensi pakan } \\
\text { Feed efficiency (\%) }\end{array}$ & $44.40 \pm 1.15^{\mathrm{a}}$ & $43.78 \pm 0.34^{\mathrm{a}}$ & $43.85 \pm 2.91^{\mathrm{a}}$ & $43.08 \pm 0.28^{\mathrm{a}}$ \\
\hline
\end{tabular}

dapat meningkatkan pertumbuhannya dan sistem immun ikan.

Tingkat sintasan ikan pada semua perlakuan menunjukkan hasil yang tidak berbeda nyata $(P>0,05)$. Hal ini menunjukkan bahwa pakan perlakuan yang diberikan dapat dimanfaatkan dengan baik dalam menjaga vitalitas hewan uji. Demikian juga efisiensi pakan menunjukkan hasil yang tidak berbeda nyata $(P>0,05)$ di antara perlakuan dan menunjukkan bahwa penambahan $\mathrm{S}$. cerevisiae $2 \% 6 \%$ dalam pakan belum bisa meningkatkan efisiensi pakan.

Berdasarkan Tabel 3 terlihat bahwa penambahan S. cerevisiae dapat meningkatkan kecernaan total pakan dan menunjukkan hasil yang berbeda nyata $(P<0,05)$ dengan pakan kontrol (tanpa penambahan $S$. cerevisiae). Kecernaan total pakan tertinggi diperoleh dari perlakuan penambahan $2 \%$ S. cerevisiae dalam pakan, meskipun cenderung menurun seiring dengan meningkatnya penambahan $\mathrm{S}$. cerevisiae dalam pakan. Wache et al. (2006) melaporkan bahwa penambahan S. cerevisiae dapat meningkatkan kecernaan pakan dan protein sehingga menghasilkan pertumbuhan dan efisiensi pakan yang lebih baik. Burrels et al., (2001) juga melaporkan bahwa nukleotida yang terkandung dalam S. cerevisiae dapat menigkatkan nafsu makan ikan sehingga pemanfaatan pakan lebih meningkat.

Tabel 3. Nilai koefisien kecernaan pakan uji yang disuplementasi S. cerevisiae dengan dosis berbeda untuk pembesaran ikan beronang

Table 3. The value of feed digestibility coefficients of test diets supplemented with different doses of

\section{S. cerevisiae}

\begin{tabular}{|c|c|c|c|c|}
\hline \multirow{2}{*}{$\begin{array}{l}\text { Peubah } \\
\text { Variables }\end{array}$} & \multicolumn{4}{|c|}{ Pakan uji (Test diets) } \\
\hline & S-0 & S-2 & $S-4$ & S-6 \\
\hline $\begin{array}{l}\text { Kecernaan total pakan } \\
\text { Feed total digestibility (\%) }\end{array}$ & $44.46 \pm 2.84^{c}$ & $53.92 \pm 1.51^{\mathrm{a}}$ & $52.48 \pm 0.38^{a}$ & $52.58 \pm 1.41^{\mathrm{a}}$ \\
\hline $\begin{array}{l}\text { Kecernaan protein pakan } \\
\text { Feed protein digestibility }(\%)\end{array}$ & $88.16 \pm 1.30^{a}$ & $87.81 \pm 0.06^{a}$ & $87.44 \pm 2.14^{a}$ & $87.39 \pm 0.60^{\mathrm{a}}$ \\
\hline $\begin{array}{l}\text { Kecernaan lemak pakan } \\
\text { Feed lipid digestibility (\%) }\end{array}$ & $87.24 \pm 1.89^{a}$ & $87.10 \pm 1.00^{\mathrm{a}}$ & $86.19 \pm 0.38^{a}$ & $86.48 \pm 1.96^{\mathrm{a}}$ \\
\hline
\end{tabular}


Penambahan S. cerevisiae sebanyak $2 \% 6 \%$ dalam pakan belum memberikan pengaruh terhadap kecernaan protein dan lemak pakan pada ikan baronang. Hal ini diduga disebabkan karena pakan tidak mengal ami proses fermentasi sebelum diberikan pada ikan, sehingga tidak terjadi perubahan kualitas pakan (protein dan lemak) dan relatif sama dengan pakan kontrol. Hal ini dilaporkan oleh Oboh \& Elusiyan (2007) bahwa proses fermentasi yang dilakukan pada pangan tradisional dapat meningkatkan kandungan nutrisi pangan pada umumnya karena terjadinya biosintesis vitamin, asam amino esensial, dan protein selama fermentasi, serta meningkatnya kualitas dan daya cerna protein.

Penambahan S. cereviceae dalam pakan ikan baronang dapat merangsang peningkatan jumlah sel darah merah (eritrosit) seperti terlihat pada Gambar 1. Dari Gambar 1 terlihat bahwa terjadi peningkatan jumlah sel darah merah seiring dengan penambahan jumlah S. cerevisiae dalam pakan, di mana jumlah sel darah merah tertinggi diperoleh dari perlakuan S6, meskipun secara statistik tidak berbeda nyata $(P>0,05)$ dengan perlakuan S4, tetapi berbeda nyata $(P<0,05)$ dengan perlakuan S0 dan S2. Peningkatan sel eritrosit ini seiring dengan peningkatan aktivitas fogositosis. Olivia-Teles \& Goncalves (2001) melaporkan bahwa salah salah satu bahan yang berpotensi sebagai imunostimulan adalah ragi roti (S. cerevisiae) maupun produk sampingan dari industri ragi roti (yeast-by product). Selanjutnya Yin et al. (2006) menjelaskan bahwa mekanisme kerja imunostimulan dalam merangsang sistem imun adalah dengan cara meningkatkan Aktivitas sel-sel fagosit.

Aktivitas fagositosis ikan yang diberi ragi roti dalam pakan tidak berbeda nyata $(P<0,05)$ dengan ikan tanpa pemberian ragi roti dalam pakan (Gambar 2), di mana aktivitas fagositosis tertinggi diperoleh dari perlakuan S6, meskipun tidak berbeda $(P>0,05)$ dengan perlakuan S4, akan tetapi berbeda $(P<0,05)$ dengan pelakuan S2. Peningkatan aktivitas fagositosis ini disebabkan karena ragi roti mengandung asam nukleat, mannan, nukleotida, dan $\beta$-glucan (Li \& Galtin, $2003 ; 2006$ ). Ini sesuai dengan pernyataan Raa (2000) bahwa â-glucan dapat meningkatkan aktivitas fagositosis dengan cara berikatan terlebih dahulu dengan molekul reseptor yang terdapat pada permukaan sel-sel fagosit. Hal yang sama dilakukan oleh Manurung et al. (2013) bahwa dengan penambahan ragi roti sebanyak $10-20 \mathrm{~g} / \mathrm{kg}$ pakan menunjukkan peningkatan aktivitas fagositosis yang lebih tinggi dibandingkan dengan ikan kontrol (tanpa pemberian ragi roti). Menurut Divyagnaseswari (2007), bahwa bahan-bahan imunostimulan dapat meningkatkan aktivitas fagositosis, komplemen, lisosim, serum Ig, dan menghasilkan peningkatan resistensi penyakit.

Parameter kualitas air yang diamati selama pemeliharaan meliputi salinitas, suhu, $\mathrm{pH}$, dan oksigen terlarut masih dalam batas optimum untuk pertumbuhan ikan baronang, berturut-turut $35 \mathrm{ppt}$; $30^{\circ} \mathrm{C}-35^{\circ} \mathrm{C}$; 7 ; dan $4-5 \mathrm{mg} / \mathrm{L}$.

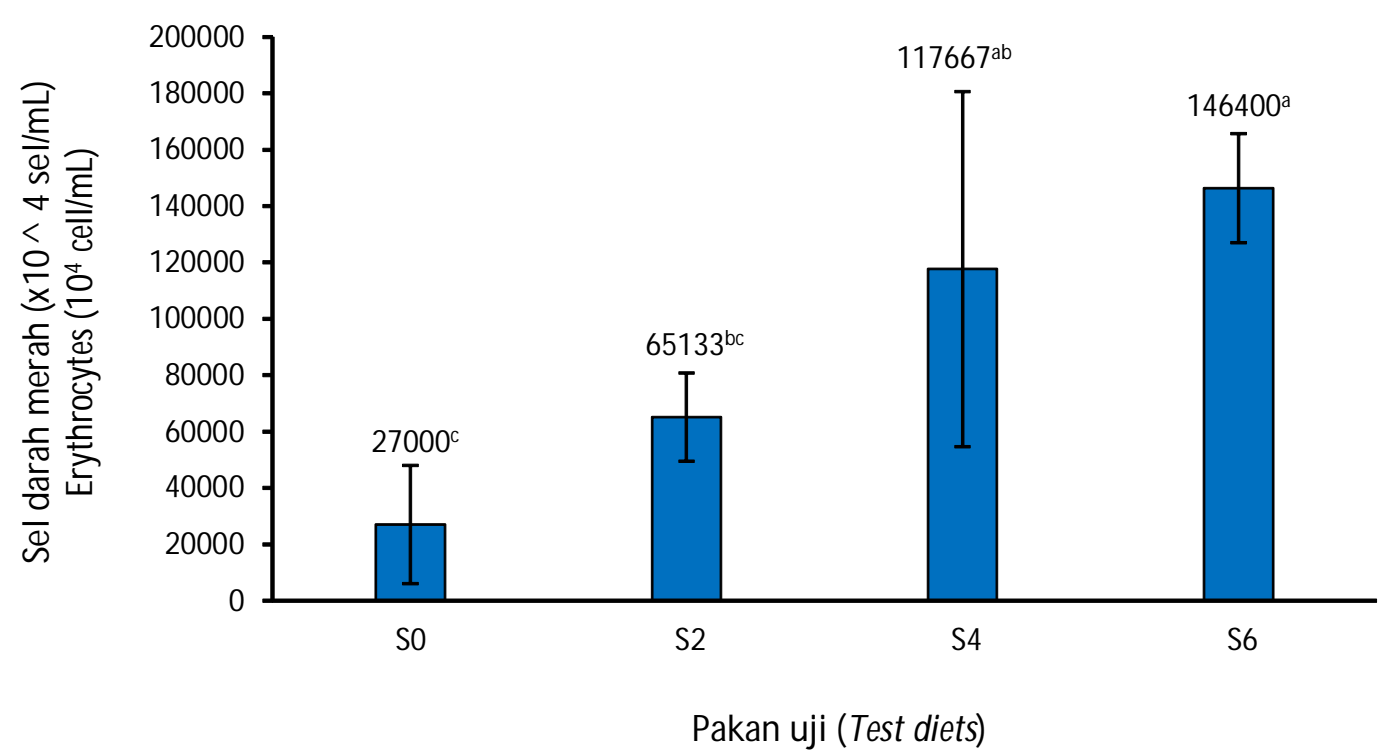

Gambar 1. Sel darah merah ikan yang diberi pakan uji yang disuplementasi S. cerevisiae dengan dosis berbeda pada pembesaran ikan beronang.

Figure 1. Red blood cells of fish fed with test diets supplemented with different doses of

\section{S. cerevisiae}




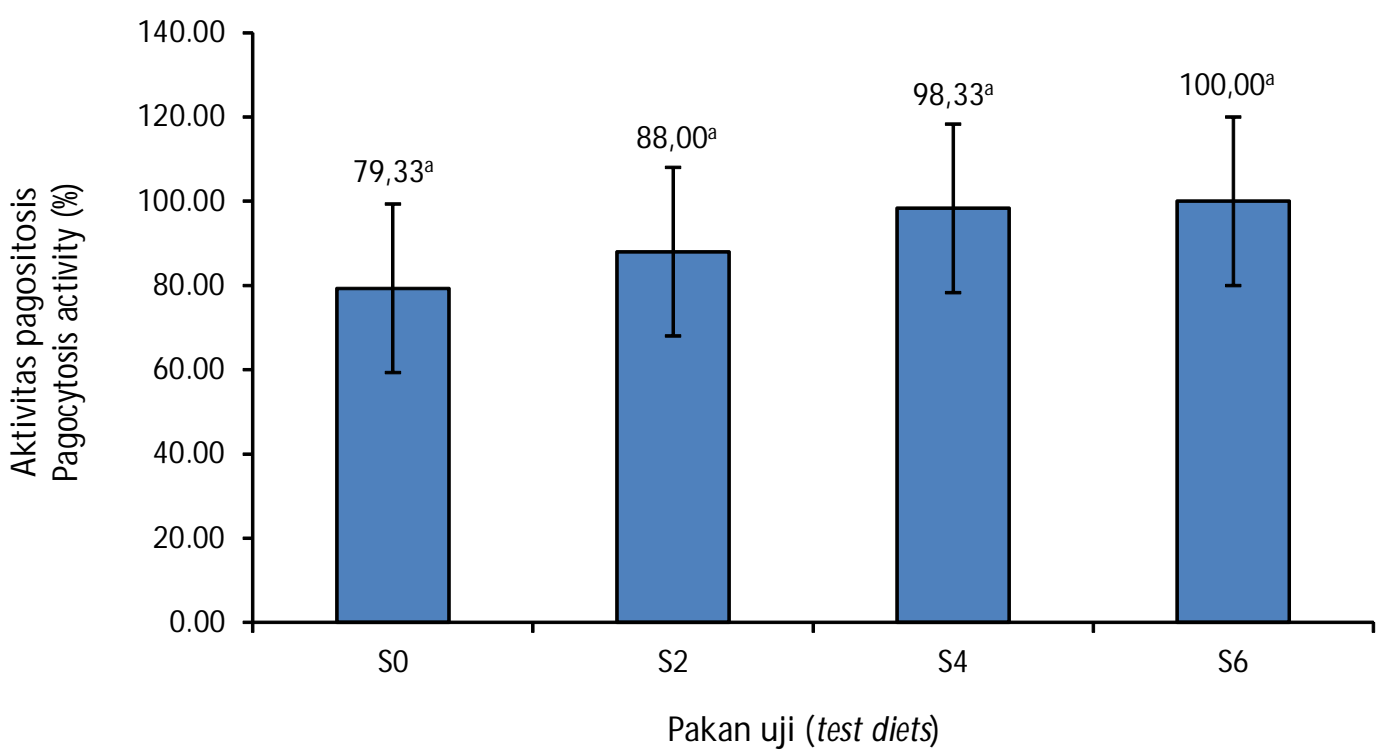

Gambar 2. Aktivitas pagositosis ikan yang diberi pakan uji yang disuplementasi S. cerevisiae dengan dosis berbeda pada pembesaran ikan beronang.

Figure 2. Phagocytosis activity of fish with fed test diet supplemented with different doses of S. cerevisiae.

\section{KESIMPULAN}

Suplementasi S. cereviceaesebanyak $2 \%$ dalam pakan dapat meningkatkan pertumbuhan dan kecernaan to tal pakan pada pembesaran ikan baronang. Sementara respons imun ikan meningkat seiring dengan peningkatan suplementasi S. cerevisiae dalam pakan. Suplementasi S. cerevisiae sebanyak $2 \%$ dalam formulasi pakan dapat diaplikasikan untuk pembesaran ikan baronang.

\section{UCAPAN TERIMA KASIH}

Sebagai penulis utama, saya menyampaikan terima kasih kepada Dr. Usman, M.Si. atas bimbingannya selama pelaksanaan penelitian dan penulisan artikel ini. Kami juga menyampaikan terima kasih kepada Saudara Jalaluddin dan Umar yang telah membantu selama kegiatan ini berlangsung baik di keramba jaring apung maupun di laboratorium basah pada saat pengambilan feses, kepada Saudara Rosni, Dian Wahyuni, dan Tamsil yang telah membantu analisis proksimat dan kromium pada pakan dan feses, serta pembuatan pakan uji.

\section{DAFTAR ACUAN}

Abdel-Tawwab, M., Abdel-Rahman, A.M., \& Ismael, N.E.M. (2008). Evaluationn of commersial live baker's yeast, Saccharomyces cerevisiae as a growth and Immunity promoter for fry nile tilapia Oreochomis niloticus (L) challenged in situ with Aeromonas hydrophyla. Aquaculture, 280, 185-189.
Afrianto, E. (2009). Pemanfaatan mikroba untuk meningkatkan efisiensi konsumsi pakan pada ikan. Skripsi. Fakultas Perikanan dan IImu Kelautan, Universitas Padjadjaran.

AOAC International. (1999). Official methods of analysis. $16^{\text {th }}$ ed. Association of Official Analytical Chemists International, Gaithersbeg, Maryland, USA. $1141 \mathrm{pp}$.

Barnes, A. (2006). Dizetary nucleotides: Essential nutrients for shrimp growth and immunity. Center for Marine Studies, University of Queensland.

Burrels, C., Williams, P.D., \& Fomo, P.F. (2001). Dietery nucleotide: A novel supplement in fish feed. 1 effects on resistance to disease in Salmonids. Aquaculture, 199, 159-169.

Divyagnaseswari, M., Christybapita, D., \& Michael, R.D. (2007). Enhancement of nonspecific immunity and disease resistance in Oreochromis mossambicus by Solanum trilobatum leaf fractions. Fish \& Shellfish Immunology, 23, 249-259.

Hardy, R.W. (1989). Diet preparation. In Halver, J.E. (ed.). Fish Nutrition. Second Edition. San Diego: Academic Press, Inc., p. 476-549.

Li, P. \& Gatlin, D.M. (2003). Evaluation of brewers' yeast (Saccharomyces cerevisiae) as a feed supplement for hybrid striped bass (Marone chrysops $x$ M. Saxatillis). Aquaculture, 219, 681-692.

Li, P. \& Gatlin, D.M. (2006). Nucleotide nutrition in fish: Current knowledge and fiture application. Aquatic, 251, 141-152. 
Life Source Basics. (2002). WGP. Beta glucan. http:www. Life Source Basics. Com/beta glucan htm. (10 Desember 2002).

Lin, Y.H., Wang, H., \& Shiau, S.Y. 2009. Dietary nucleotide supplementation enhance growth and immune response of grouper, Epinephelus malabaricus. Aquac., 15, 117-122.

Manurung, U.S., Manoppo, H., \& Tumbol, R.A. (2013). Evaluation of baker's yeast Saccharomyces cerevisiae, in enhancing non specific immune response and growth of nila tilapia Oreochromis niloticus. E-journal Budidaya Perairan, 1(1), 8-14.

Oboh, G. \& Elusiyan, C.A. (2007). Changes in the nutrient and antinutrient content of micro-fungi fermented cassava flour produced from low and medium cyanide variety of cassava tuber. African Journal of Biotechnology, 6(18), 2150-2157.

Olivia-Teles, A. \& Goncalves, P. (2001). Partisial replacement of fishmeal by brewers yeast Saccharomyces cerevisiae, in diest for sea bass Dicentrachus labrax juveniles. Aquaculture, 202, 269-278.

Pais, R., Khushiramani, R., \& Karunasagar, I. (2008). Effect of immunostimulan on hemolymph haemagglutinins of tiger shrimp Penaeus monodon. Aquac. Res., 38, 1339-1345.

Raa, J. (2000). The use of immunestimulant in fish and shell fish feeds. University of Tromso Norway.

Sajeevan, T.P., Philip, R., \& Singh, I.S.B. (2006). Immunostimulatory effect of a marine yeast Candida sake S156 Fenneropenaeus indicus. Aquaculture, 257, 150-155.

Schulz, C., Knaus, M., Wirth, M., \& Rennert, B. (2005). Effect of varying dietary fatty acid propile on growth performance, fatty acid, body and tissue composition of juvenile pike perch (Sander lucioperca). Aquaculture Nutrition, 11, 403-413.
Stell, R.G.D. \& Torrie, J.H. (1995). Prinsif dan prosedur statistika. Alih bahasa: Bambang Sumantri. Jakarta: Gramedia Pustaka Utama, $748 \mathrm{hlm}$.

Stolen, S.J. (1990). Techigues in immunologi 1st edition. SOS Publication 43 de Normandie, A, Venue Fair Haven, N.J., 07703-3303.

Takeuchi, T. (1988). Laboratory work-chemical evaluation of dietary nutrient. In Watanabe, T. (Ed.). Fish Nutrition and Mariculture. Department of Aquatic Bioscience, Tokyo University of Fisheries, p. 179-233.

Verschuere, L., Rombaut, G., Sorgeloos, P., \& Verstraete, W. (2000). Probiotic bacteria as biological control agents in Aquaculture. Microbiolgical and Molecular Biology Review, 64, 655-671.

Wache, Y. F., Auffray, F.L., Gatesaupe, Zurrbonino, J., Gayet, V., Labbe, L., \& Quentel, C. (2006). Cross effect of the strain dietary, Saccharomyces cerevisiae, and rearing condition on the onset of intestial microbiota and digestive ezymen rainbow trout, Onchorhynchus mykiss fry Aquaculture, 258, 470-478.

Welker, T.L., Lim, C., Aksoy, M.Y., Shelby, R., \& Klesius, P.H. (2007). Immune response and resistance to stress and Edwarsiella ictaluri challenge in channel catfish, Ictalurus punctatus, fed diet containing commercial whole-cell yeast or yeast subcomponents. J. World Aquac. Soc., 38(1), 24-31.

Wotzon, J.D., Tooze, J., \& Kurts, D.T. (1988). DNA rekombinan suatu pelajaran singkat. Alih Bahasa Wisnu Gunarso. Penerbit Airlangga.

Yin, G., Jeney, G., Racz, Y., Pao, X., \& Jeney, Z. (2006). Effect of two Chinese herbs (Astragalus radix and Scutellaria radix) on non-spesipik immune response of Tilapia, Oreochromis niloticus. Aquaculture, 235, 39-47. 